\title{
Research on the Reform of Basic Art Course of Industrial Design Major from the Perspective of Teaching and Learning
}

\author{
Liping Peng \\ Neusoft Institute Guangdong \\ Foshan, China
}

\begin{abstract}
Industrial design major belongs to engineering type, and the art foundation of students is insufficient, which affects the realization of professional training objectives. This paper starts from the current teaching situation of students majoring in industrial design with weak art foundation, takes students majoring in industrial design with "zero" art foundation as the research object, and analyzes the advantages and disadvantages of the interactive and interest teaching mode for the students of industrial design majors, and explores a new way for "zero" art foundation students to realize the teaching mode docking with "zero" obstacle of design major.
\end{abstract}

Keywords-zero art foundation; interest teaching; zero obstacles docking

\section{INTRODUCTION}

The art foundation is very important for a designer, especially the hand-drawing ability. In the early stage of work creation, hand-drawing plays a very key role in the conception of designer. Before the proposal, the idea can also be drawn by hand to avoid duplication of work. The hand-drawn prototype drawings can be used for communication schemes, and can also be placed in later packaging displays to make the works more attractive. More and more visual manuscripts are used in hand-drawn illustration to increase the sense of visual impact and bring a brand-new experience to customers. In order to improve the aesthetic and design sense of graphics, it is necessary to have a certain foundation of fine arts when using computer to design graphics.

In the professional directory issued by the Ministry of Education in 2012, the major of industrial design is enrollment as an engineering major, requires students to have high academic scores in the course of culture, while their foundation in fine arts is somewhat weak, and in view of the concept of "new engineering" proposed by the Ministry of education in 2017, all of these brought new opportunities and challenges to the development of industrial design teaching.

The basic courses of fine arts shoulder the main task of modeling training, which is of great significance for strengthen art foundation of students, and improve professional aesthetic ability and creative thinking ability of students. Therefore, it is necessary to innovate and reform in accordance with the times and market demand to improve the relevance and quality level of teaching. [1]

\section{ANALySis OF CURRENT SituATION OF TEACHING AND LEARNING}

Art Foundation is a basic course in the design specialty, and also a required aesthetic practice course in the industrial design major. Through this course, students can understand the three most important relationships in design: structural relationship, sketch relationship, and color relationship. It is a compulsory course connecting the preceding and the following to improve the modeling and color matching ability and exercise practical ability of students. [2]

In the 2012 subject catalogue of the Ministry of education, industrial design majors are only recruited as engineering majors, while most of the original colleges and universities recruit art students under the name of industrial design majors. This provision of the Ministry of Education is a strong impact on many colleges and universities, which are faced with the problem whether to continue or give up recruiting students. If they continue to recruit students, they will not have enough teachers; If the enrollment is abandoned, there is no place for the existing teachers.[3] After weighing the advantages and disadvantages between the two situations, many colleges and universities choose to continue to recruit students, but there are more or less contradictions and problems:

\section{A. The Curriculum is not Reasonable Enough}

Since the teachers with previous product design background are still used in teaching, there are not much difference between the teaching methods and contents and the product design major of art students. They are all line practice at the beginning, followed by gypsum, and then plaster figure. Although the students completed the tasks in accordance with the teacher's regulations, most students still feel that they have not figured out the way, so that they doubt the role of the course in the major after completing the course, even many students feel confused about the future because of the art foundation course, which undoubtedly deviates from the original training goal. 


\section{REFORM MEASURES BASED ON THE CURRENT SITUATION OF TEACHING AND LEARNING}

Only as an engineering major to recruit students means that the students are all "zero" art foundation students. According to the survey, the students who apply for the industrial design major basically have three characteristics:

1) Recognizing the development prospects of the industry: In recent years, the industrial design major has received high attention from the government. For example, the "Mayor's Cup" and "Provincial Governor's Cup" industrial design competitions promoted by provinces and cities in China, in order to make people aware of the importance of industrial design; with the strong support of the government and the needs of the market, more and more talents will devote themselves to the industrial design industry; and with the gradual improvement of people's living standards, simple functional products can no longer meet people's living needs, and industrial design is urgently needed to bring light to the stagnant market. Throughout the past few years, the enterprises with good development momentum at home and abroad are all enterprises that attach importance to design, such as Apple, Mi and so on, which have achieved their achievements only when they attach great importance to industrial design. Therefore, with the development of the Internet, industrial design is the only way for science students to enter the design major, so it is a natural choice for them to apply for the industrial design major.

2) They are interested in industrial design: These students usually have a little art foundation. Now the enrollment and training objects are all post-2000s generation, and the family conditions are generally better. Many students have taken art related extracurricular counseling classes, so they choose majors that can give full play to their strengths.

3) The students of industrial design major are more rational and have a more accurate grasp of technology: They are basically engineering background, in the product structure, technical principles and other grasp will be more rational, while the students of product design are all art students, which are relatively perceptual, so the choice of industrial design major can be greatly different from the product design major with a foundation in fine arts.[5]

4) They have a weak foundation in fine arts: Some students may have taken similar tutorial classes and learned some basic sketch, Chinese painting and so on, but there is still a big gap from the requirements of industrial design major.

In summary, the limitation of teacher teaching in terms of teaching situation makes industrial design indistinguishable from traditional product design. In terms of learning situation, the basic "zero" art foundation of students makes the basic design courses progress slowly, and it is difficult for students to think that this is a compulsory course, so it has a strong rejection psychology.
How to train the students of "zero" art foundation and realize the connection with the professional "zero" obstacles is the problem that industrial design teachers should always pay attention to. Based on the current situation of teaching and learning, this paper proposes the following specific reform measures:

\section{A. Reform of Teaching Methods}

Drive the majority with a few, learn in small groups first, and finally achieve comprehensive progress. Before class, the teacher made a thorough study of the classmates, and selected the students who have a basic knowledge of art and interested as the leader of each group. The team leader needs to collect and sort out relevant classroom materials and forward them to the team members for preview. The group leader shall organize extracurricular tutoring and study time for the group members. In this way, each group is required to display all the works of their group through the WeChat circle of friends, class groups and public numbers in the prescribed time, and finally decide the champion and second runner-up group by voting. After class conclusion, the champion and second runner-up of each group should be rewarded and scored.

\section{B. Reform of Teaching Content}

The teacher gives different topics in the class every week, let the students choose the topics they are interested in, and then the teacher makes targeted comments and gives relevant suggestions based on the creations of students. This method can not only bring students into the study of art imperceptibly, but also train the creative consciousness of students.

The specific teaching reform content is divided into the following five stages:

1) The first stage, 3 to 4 weeks, consolidating the foundation for entry: This stage mainly combines the characteristics of industrial design, practice various lines of drawing, such as long line, short line, arc line, row line, wave line and so on, so that students have a certain understanding of the lines, and find their own style of lines. The next step is to cultivate preliminary aesthetic consciousness by the practice of line arrangement, multiturn lines and so on, such as first heavy then light, first light then heavy, two ends light, two ends heavy and so on. Although it is a simple line arrangement exercise, each piece must be work to form a picture with a story, and avoid doodled aimlessly. The scoring criteria for the first stage are as follows "Table I":

TABLE I. SCORING CRITERIA 1

\begin{tabular}{|l|l|l|l|}
\hline Subdivisions & Smooth lines & $\begin{array}{l}\text { Picture } \\
\text { harmony }\end{array}$ & $\begin{array}{l}\text { Story sense of } \\
\text { pictures }\end{array}$ \\
\hline Score & $30 \%$ & $35 \%$ & $35 \%$ \\
\hline
\end{tabular}


5) The fifth stage, more than 5 weeks, the color design stage: This stage mainly learns color extraction, color redesign, and color application design. Color matching is a problem faced by many art students and non-art students, and industrial design majors pay more attention to product color matching requirements. Different color combinations of the same product show different product values. In this stage, every training should impress the students, so as to facilitate the later learning and application. The fifth stage is scored as follows "Table V":

TABLE V. SCORING CRITERIA 5

TABLE II. SCORING CRITERION 2

\begin{tabular}{|l|l|l|l|}
\hline Subdivisions & $\begin{array}{l}\text { Smooth } \\
\text { lines }\end{array}$ & $\begin{array}{l}\text { Picture restoration } \\
\text { degree }\end{array}$ & $\begin{array}{l}\text { Brings own } \\
\text { creation }\end{array}$ \\
\hline Score & $35 \%$ & $25 \%$ & $40 \%$ \\
\hline
\end{tabular}

3) The third stage, about 3 weeks, according to the prototype creation stage: The teacher gives the prototype, and the students transform their creation through their own style and creation concept. For example, the prototype is badminton, students derived from badminton and other similar to the shape or function of badminton products, first individual evolution, gradually to associate a scene, according to the scene and then derived a batch of products. This stage is the application of the previous two stages of training, but also creative and aesthetic training stage. Through the bold deformation and creation, students gradually form a sense of creation, so that students can see the results of the creation after the "zero" basic training. The scoring criteria for the third stage are as follows "Table III":

TABLE III. SCORING CRITERION 3

\begin{tabular}{|l|l|l|l|}
\hline Subdivisions & Smooth lines & $\begin{array}{l}\text { Subject } \\
\text { deformation } \\
\text { creation }\end{array}$ & $\begin{array}{l}\text { Derivative scene } \\
\text { and product } \\
\text { creation }\end{array}$ \\
\hline Score & $25 \%$ & $35 \%$ & $40 \%$ \\
\hline
\end{tabular}

4) In the fourth stage, about 3 to 4 weeks, the $3 D$ effect performance improvement stage: This stage is to consolidate and strengthen the previous stages. In this process, students will get a deeper exposure to the three most important aspects of the sketch relationship and the five major and structural relationships. For example, grasp the perspective relationship, the product will have a sense of reality when it is displayed. In the structural relationship must be familiar with the perspective relationship: one point perspective, two points perspective, and three points perspective. The fourth stage is scored as follows "Table IV":

TABLE IV. SCORING CRITERIA 4

\begin{tabular}{|l|l|l|l|}
\hline Subdivisions & $\begin{array}{l}\text { Smooth } \\
\text { lines }\end{array}$ & $\begin{array}{l}\text { Accurate } \\
\text { perspective }\end{array}$ & $\begin{array}{l}\text { Accurate structure } \\
\text { performance }\end{array}$ \\
\hline Score & $25 \%$ & $35 \%$ & $40 \%$ \\
\hline
\end{tabular}

TABLE VI. ASSESSMENT CRITERIA

\begin{tabular}{|l|l|l|l|l|}
\hline Project & $\begin{array}{l}\text { Group } \\
\text { appraisal }\end{array}$ & $\begin{array}{l}\text { Normal } \\
\text { performance }\end{array}$ & $\begin{array}{l}\text { Color } \\
\text { design }\end{array}$ & Attendance \\
\hline Score & $30 \%$ & $30 \%$ & $30 \%$ & $10 \%$ \\
\hline
\end{tabular}

\section{Reform of Teaching Resources}

At present, in addition to the Internet and libraries, another important resource for teaching resources is the teachers themselves. [7] Since it is learning, there must be teachers, so as knowledge initiators of teaching, teachers should first cultivate themselves to be the best in their profession. Only by master the professional knowledge, it is possible to train the students to become high-level talents. In terms of knowledge and skills, teachers should not be limited to a certain category, but should absorb and dabble in all 
basic art teaching, it is necessary to carefully reform and improve the teaching work plan in accordance with the characteristics of teaching and learning, earnestly set up each course, grasp each teaching link, constantly improve the teaching mode and teaching concept, timely find out and solve the relevant problems in the teaching process, accumulate rich teaching experience, and strive to improve the comprehensive ability of students.

\section{REFERENCES}

[1] Peng Liping. Research on the Basic Art Course of Digital Media Specialty Based on the Perspective of teaching and Learning [J]. Artist, 2018, 04: 53-55. (in Chinese)

[2] Design Tree. The Basics of Art That Designers Must Understand [EB/ OL].https: //baijiahao.baidu.com/s? Id = 1598510112642117878 $\&$ qq-pf-to = pcqq.c2c, 2018-04-23. (in Chinese)

[3] Wan Yuji. Reform of Basic Art Course for Environmental Design Major Based On Vocational Ability Training [J]. Art Education, 2019, 09: 176-177. (in Chinese)

[4] Zhao Dingding. Exploration and Research on the Innovation Mode of Basic Education of Fine Arts Majors [J] .Researches in Fine Arts Education, 2019,11: 106-107. (in Chinese)

[5] Blow in the Wind Shine. A Brief Talk on the Current Situation and Future Development Trend of Industrial Design [EB/OL].https://wenku.baidu.com/view/6161019f690203d8ce2f0066f 5335a8102d266cd.html,2018-07-12. (in Chinese)

[6] He Renke, Liu Guanzhong. History of Industrial Design (4th Edition) [M]. Higher Education Press: Beijing, 2010-07: 1-. (in Chinese)

[7] Ma Rui, Zhang Xuetang, Ru Jing. Research on the Implementation Path of University Innovation and Entrepreneurship Education [J] China Off-School Education, 2019, 33: 98-99. (in Chinese)

[8] Liu Fanxiang. Investigation and Countermeasures on the Use of Mobile Phones by Vocational College Students in the New Media Era [J]. The Age of Think Tanks, 2019, 40: 56-58. (in Chinese)
As an indispensable portable object carry-on in modern life, mobile phone should also play its role in teaching, so that it is no longer just a platform for information contact and entertainment.[8] By browsing the latest industrial design works, purchasing some members of the industrial design resource library, and learning professional knowledge online, and so on, it enables students to think about their shortcomings in the process of playing mobile phones and stimulate learning interest.

\section{Grasping the Degree of "Interest"}

The emphasis of this course reform is to stimulate students' interest and group supervision to drive teaching, so it is very important to grasp the degree of "interest" in teaching. If this degree is not well controlled, students will lose their confidence in learning in a disguised way.

\section{CONCLUSION}

The basic art course is one of the basic compulsory courses of the industrial design major, which is the basis of all the teaching activities of the major. It plays a vital role in many later courses or projects. Even the most delicate materials are sometimes not as good as some hand-drawn original graphics. Hand-drawn graphic illustrations can reduce the sense of material and give users a fresh visual display. The quality of basic art education is directly related to the quality of the teaching of the entire major, as well as the level of design creativity of digital media students. In the 